\title{
Prospects of the exchange future market in the development of the agrarian economic system of Ukraine
}

\author{
Nadiia P. Reznik \\ Doctor of economic sciences, professor \\ head of Department of Exchange \\ Activity and Trade \\ National university of life and \\ environmental science of Ukraine \\ Kyiv, Ukraine \\ https://orcid.org/0000-0001-9588-5929
}

\author{
Anna M. Slobodianyk* \\ $P h D$ (in Economics), \\ associate professor of the department \\ of Exchange Activity and Trade \\ National university of life and \\ environmental science of Ukraine \\ Kyiv, Ukraine \\ https://orcid.org/0000-0001-6437-0033 \\ Mykola A. Horlachuk, \\ PhD (in Economics), Associate \\ Professor, \\ Senior Research Fellow, Research \\ Department, \\ Ternopil National Economic University \\ Ternopil, Ukraine \\ https://orcid.org/0000-0001-8030-1193
}

\author{
Oksana V. Sydorenko \\ Doctor of economic sciences, associate \\ professor, \\ Professor of Department of Marketing \\ and Business Management \\ National University of Kyiv-Mohyla \\ Academy \\ Kyiv, Ukraine \\ https://orcid.org/0000-0002-5671-2133
}

\begin{abstract}
The article is devoted to the problem of exploring the prospects for the development of a futures market in the agrarian sector of the economy, which will provide savings for agricultural producers by increasing their creditworthiness, protection against possible fluctuations of prices, clearer planning of their production and equal conditions of competition. It is proved that the use of derivatives by domestic producers and exporters makes it possible to increase the level of efficient production and sale of agricultural products. The nature of the futures exchange market is characterized by being able to predict prices of agricultural products with great precision, and thus to protect future harvests, especially cereals, from unwanted price fluctuations, which is possible with natural relationship between spot and futures. It is justified that price stabilization due to the efficient operation of the futures market increases the creditworthiness of agricultural producers and reduces the cost of bank credit.
\end{abstract}

Keywords-exchange commodity market, agricultural market, forward, futures, simple warehouse certificate, market of warehouse certificate.

\section{INTRODUCTION}

The agrarian market holds a significant place in the structure of the economy of Ukraine and its further development is impossible without effective economic mechanisms for sale of agricultural products, in particular without relevant economic organizations, among which it is necessary to highlight stock exchanges. Considering the imperfection of the modern stock market of Ukraine and, as a consequence, the futures market, and the availability of sound world experience in its cost-effective organization, it is worth to synthesize this experience and current world tendencies of development of stock markets, taking into account the domestic peculiarities of management. All these pointsshow the need to develop a national futures market in the agricultural sector. The use of derivatives by domestic producers and exporters would increase the efficiency of production and sales of agricultural products. Problems which are connected with development of stock trading for agricultural enterprises, and especially futures markets, are covered in various aspects in the scientific works of such foreign and domestic scientists as M. Hernandez, S. Irvin, J.K. Hull [1], D. Sanders [2], G. Cherevko, Yu. Ruban [3], A. Rozgon, O. Mograb, V. Savchenko, O. Sohatskaya, A. Slobodianyk [4], O. Shpychak and others. In particular, J.K. Hull analyzed the nature, history of development and importance of derivatives markets within the current economic system, considered the peculiarities of conducting transactions with interest rate futures, swaps and options [2]. $\mathrm{Yu}$. Ruban offers different approaches to insurance of prices for agricultural products through futures contracts [3]. The futures market, with a small number of high-tech modern certified warehouses which are located at major ports and transport hubs, particularly at borders, can and should serve a futures market where few real-world transactions are conducted. A certified broker should come to these exchanges, who, in cooperation with market analysts, will be able to enter into futures and option contracts for the main commodities, foreign currency and most liquid securities, as notes Slobodianyk A. [4]. At the same time, the complexity and versatility of issues related to the development of futures markets in the agrarian sector of the economy necessitate its further study.

\section{THE PURPOSE OF THE RESEARCH}

Is to highlight the prospects for the development of a futures market in the agricultural sector with implementation of global experience, which will provide savings to agricultural producers by increasing their creditworthiness, protection against possible price 
fluctuations, clearer planning of their production and equal conditions of competition.

\section{RESULTS}

The modern stock market cannot be imagined without such instruments as derivatives. A derivative is a financial instrument whose value is derived from the value of the base variables. Typically, these variables are prices for various market assets. The basic asset of the first derivative security was agricultural crops. In stock terminology, there is another name for these financial instruments - fixed-term stock contracts. The most common fixed-term contracts on modern stock exchanges are futures contracts and options. Futures contracts appeared as the result of the evolution of stock trading. They were preceded by forward contracts, which are also one of the types of fixed-term contracts (derivatives) that are currently in circulation mainly on the over-the-counter market or in the stock markets of real goods. Forward contracts have inherent credit risks. Given its over-the-counter nature, they are not highly liquid due to lack of clear standardization.

A more advanced type of derivative is a futures contract, which is an agreement between the seller and the buyer in the future to supply a particular good at a pre-agreed price. The futures contract is standardized in terms of quality, quantity and other characteristics. The only variable of a futures contract is its price, which varies depending on the market situation. Global futures contracts have gained popularity after the introduction of the Chicago Commodity Exchange for Agricultural Products in 1865 [2]. Futures contracts were signed earlier in Europe and Japan, but its introduction into the US stock market was a decisive factor in the development of fixed-term trading.

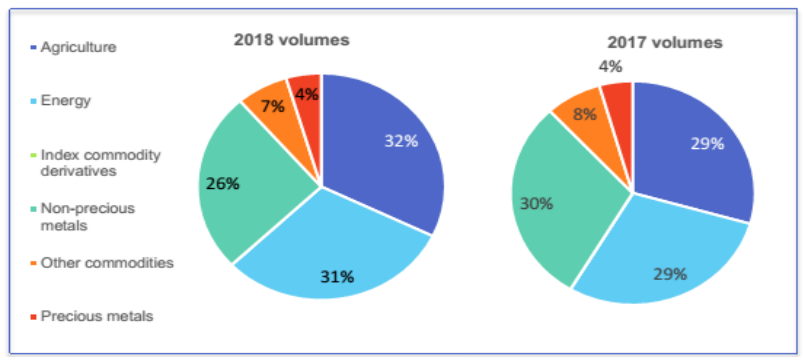

Source: [5]

Fig. 1. Commodity derivatives trading statistic, products

Objects of trading in the futures markets today is the rights to various basic assets: interest rates, stock indices, commodities, alternative investments, energy, metals, exchange rates. But the most common basic asset for futures contracts in the last two decades has been agricultural products - that is about $70 \%$ of futures contracts. The volume of world futures contracts for corn and sugar is more than three times the volume of its physical production [2].

At the same time, futures contracts are an effective financial instrument that enables market participants to hedge price and market risks in real-world markets. Today, there are more than two hundred futures markets in the world. Due to the imperfection of the legal framework on the organization of stock exchange activities, especially regarding the conclusion of fixed-term contracts, the fragmentation of agriculture, the crisis situation of most agricultural enterprises, the low level of marketability of domestic agricultural products, the practical absence of stock exchange infrastructure in our country, exchange trading doesn't have appropriate level. Therefore, despite the presence of almost six hundred exchanges, agricultural enterprises sell through them a meager part (within a percentage) of grain (wheat, barley, corn, etc.). Similar is the situation with sunflower seeds, with almost no sugar trading.

In the world, most agricultural market participants use the stock market to manage risks, including to protect against potential price fluctuations. As noted above, the futures market provides such opportunities. A feature of futures contracts is standardization. There is virtually no risk of contract failure: an open position can be closed any day. In this case, physical delivery of the goods is optional, the duration of the contracts is up to 18 (even 36 months). Futures are an important hedge, as they can protect against adverse cash market developments, leading to overall market stability as buyers and sellers gain more security in their transactions. Futures markets, having survived all other pricing mechanisms in the agrarian market in time and efficiency, play a major role in today's risk management system. Prominent US stock market specialist D. Sanders rightly states that futures markets are a continuation of the physical markets [6]. They were formed in the process of market evolution; its purpose is to improve the functioning of physical markets. That is why, in order to understand the futures market, one must know very well the underlying asset market, i.e. the physical market. With this interaction, futures markets are the place where the price of a product is formed.

Futures price is a referent price for manufacturers, processors and consumers of goods and services, both nationally and internationally. In Europe, the leading position in the commodity derivatives trade is held by the MATIF Paris stock exchange, which belong to Nyse Liffe Group. On this stock exchange traded kinds of contracts for agricultural products, such as rapeseed, corn, flour, wheat, brewery barley, rapeseed oil.

TABLE I. COMMODITY DERIVATIVES TRADING STATISTIC, VOL

\begin{tabular}{|l|r|r|r|}
\hline Category & Vol-2018 & Vol-2017 & $\%$ change Y-o-Y \\
\hline Agriculture & 1906498461 & 1734334851 & $9.9 \%$ \\
\hline Energy & 1815789033 & 1709489894 & $6.2 \%$ \\
\hline Index commodity derivatives & 1443103 & 113076 & $1176.2 \%$ \\
\hline Non-precious metals & 1522680271 & 1741973887 & $-12.6 \%$ \\
\hline Other commodities & 400669143 & 438752259 & $-8.7 \%$ \\
\hline Precious metals & 271817771 & 259667301 & $4.7 \%$ \\
\hline Grand Total & 5918897782 & 5884331268 & $0.6 \%$ \\
\hline
\end{tabular}

The futures market also has advantages over the physical one, which is that all contracts on the market are standardized and meet pre-established delivery times. For example, the volume of a wheat flour contract at MATIF is50 tons. Quality indicators should be as follows: specific weight $-76 \mathrm{~kg} / \mathrm{l}$, humidity $-15 \%$, damaged grains $-4 \%$, sprouted grains $-2 \%$, percentage of impurities $-2 \%$. The place of delivery of the wheat is the port of Rouen (France). The date of delivery or the time when the buyer receives the goods and the seller pays is also defined. Such standardization guarantees high liquidity of the market, that 
is, sellers and buyers are easily found on the same contracts, they only discuss the price. At the end of 2018, the total percentage in interest rate of futures and options was 159.2 million, that is up $22.8 \%$ from the end of 2017, it is the highest level which the industry has ever seen.

The analysis of the conditions of commodity markets in Ukraine, conducted by international experts, gives grounds to define that the agricultural sector of the economy is the most promising for starting a derivatives market. Thus, today in the agroindustry the markets of the basic types of agricultural products and food are formed, the activity of which is based on modern infrastructure and the guaranteed markets of sales, there are sufficient volumes of private capital invested in real for its reproduction of the sphere (infrastructure development, new technologies, etc.) and requires economic mechanisms to limit financial risks.

TABLE II. VOLUME OF DERIVATIVES TRADING ON THE STOCK EXCHANGE AND OVER-THE-COUNTER MARKET OF UKRAINE IN 2013-2017, BILLION UAH

\begin{tabular}{|l|c|c|c|c|c|c|}
\hline Type of market & 2013 & 2014 & 2015 & 2016 & 2017 & 2018 \\
\hline Stock exchange & 0 & 0,01 & 0,04 & 0,12 & 0,59 & 0,06 \\
\hline Over-the-counter & 18,01 & 9,59 & 5,83 & 2,28 & 5,03 & 2,65 \\
\hline Total & 18,01 & 9,6 & 5,87 & 2.4 & 5,62 & 2,71 \\
\hline
\end{tabular}

Source: [6]

Analyzing Table 2, we can conclude that currency futures contracts (UAH 1.59 billion) and commodity futures (UAH 223.7 million) have been in demand in the stock market in 2018. The derivatives market has been declining over the last three years.As of 2018, the volume of derivatives trading amounted to UAH 2.71 billion. In the overall structure of trading in the securities market, the share of derivatives trading was $0.46 \%$ of the total trading in the stock market. The volume of derivatives trading on the stock market in 2018 amounted to 2.65 billion UAH. When viewed by market type, all transactions were carried out in the time market section. The most common derivatives in the Ukrainian market are futures and currency options (US dollar), commodities (oil, gold).

Attempts to launch futures mechanisms belong to the second half of the 1990s, when the Presidential Decree on "Measures to Reform Agricultural Relations" and the Cabinet of Ministers of Ukraine Resolution on the "Concept of Development of the Agricultural Market Stock Market" appeared. In particular, it envisaged the development of rules and the introduction of trading futures and forward contracts for the purchase of agricultural products on agricultural exchanges. Then there were other relevant resolutions of the Government and the Verkhovna Rada of Ukraine and orders of the relevant ministry. Finally, the participants of the agrarian market in 2003 created the "Ukrainian Futures Exchange", which planned to organize the trading of futures contracts in the same year. However, this has not happened yet.

New expectations for the launch of futures trading market participants associated with the Cabinet of Ministers of Ukraine of May 25, 2011, which approved the Memorandum of Understanding between the Government of Ukraine, the National Bank of Ukraine and the Chicago Mercantile Exchange (CME). Earlier, a similar memorandum was signed with the European exchange Euronext. However, the optimistic news for all Ukrainian farmers of June 6, 2012, began with trading futures contracts for the Black Sea wheat at the Chicago Board of Trade (CBOT), USA. For the first time since independence, a global event has inspired Ukrainian producers. Firstly, they will have guidance on the price of the future harvest and the long-awaited opportunity to insure the prices of produced products.

The efforts of the Chicago Mercantile Exchange and Euronext to spread knowledge about futures trading in Ukraine should be noted. The training seminars that these respected structures hold for Ukrainian specialists, the competition between these leading exchanges for the Ukrainian agricultural market and our cooperation with them are extremely useful for creating a modern domestic market for commodity and financial derivatives. However, derivatives trading on Ukrainian agricultural products should take place on domestic exchanges, not on foreign trading floors. A country that owns $40 \%$ of the world's black soil is already a leading exporter of many agricultural commodities, has the right and must independently shape world prices for these strategic products.

There is now an acute shortage of qualified personnel in the field of risk management in Ukraine now as review of derivatives market shows. Also, there is no motivation to hedge price risks with futures and options, lack of transparency in pricing and very weak stock exchange infrastructure. These problems are situated in the base of development a highly efficient model of building a timely commodity market for agricultural products. One of the first problems in building a civilized and efficient futures market is the confidence of its participants, which should be based on the full awareness of its participants for each of the entities and the economy as a whole figure 2 .

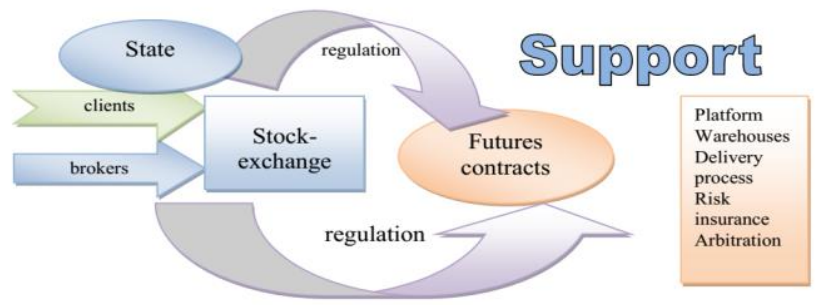

Source: Compiled by authors on the base of generalization of conducted research

Fig. 2. The offered model of stock-exchange and its activity in the economic environment of Ukraine

Participant confidence and support of commodity producers can be achieved only through the full transparency of all possible trade rules that are clearly stipulated, with strict regulation of all the rights and obligations of the parties by all market participants. Also, separately it should be noted the trading platform, contracts, brokers, clients, regulation, stock exchange, government, warehouses, delivery and settlement processes. The whole system is customized for the client, it provides the opportunity for the client to freely control the processes that are necessary for the operation of the stock market in Ukraine. In our opinion, it is advisable to consider approaches of improvement of the stock exchange mechanism from the standpoint of the most interested units in the functioning of commodity exchanges in Ukraine. 
In order for futures trading mechanisms will finally begin to work in the domestic field, it is necessary to make a lot of organizational and legislative efforts, to overcome many false stereotypes and barriers to reach the goal [7]. The most important prerequisite is to understand the nature of these mechanisms and the basics of its effective functioning and regulation by all those involved in such an important case [8]. Today, the Agrarian Exchange is preparing for the creation of a fixed-term market, which provides for the full operation of the clearing center, futures contracts in the national currency, the electronic auction platform and other innovations [9]. The main objective is to introduce domestic currency denominated futures. This contract will be aimed at Ukrainian participants of the stock market agrarian market. According to forecasts of the leadership of the Agrarian Exchange, futures should appear on the market in a few years [4].

For the successful implementation of this project, the Agrarian Exchange has already begun negotiations with leading consultants and consulting companies on the development of the stock market, who have tremendous experience in the development of the stock market in the world.

According to experts of the Agrarian Exchange, an effective exchange market will give many benefits for the agrarian industry and the state as a whole. For example, it is the opportunity for an agricultural producer to sell their products at market prices. On the basis of exchange mechanisms, a fair price will be formed at which export operations will be carried out. The consequence of these tools will be that the farmer will have additional funds that he can use to increase yields, develop new technologies, and purchase equipment.

In addition, the futures market will help the buyer and seller hedge their price risks. Therefore, fluctuations in world markets will not significantly affect the income of agrarians, as well as the agrarian industry of our country. Agrarians will have confidence in their income for the year and will not worry about losing a "good" price, because all their possible losses or theoretical income will be transferred through a futures contract to speculators [10]. It is they who will bear the risk of price fluctuations. The ability to secure prices through futures trading in the future will ensure the prosperity of agricultural enterprises, the development of the financial sector of the country, as banks are more willing to finance the agrarian sector, as well as the realization of the production and export potential of agroindustry of Ukraine.

\section{CONCLUSIONS.}

A country that has a leading position in the world in agricultural production (especially grain) must have a strong market infrastructure, especially a futures exchange market, that provides transparent, fair pricing that affects the global economy and helps to secure various types of insurance risks. Futures markets have several functions, the most important of which are:

- simplification of price risk management; assistance to companies in forward pricing;

- providing enterprises with tools to raise and protect additional operating capital;

- providing information to make adequate management decisions.

An advanced futures market is able to predict agricultural prices with great precision and therefore to protect future crops, especially cereals, from unwanted price fluctuations. This is possible with the natural relationship between spot and futures prices. Price stabilization through efficient operation of the futures market increases the creditworthiness of farmers and reduces the cost of bank credit. Futures trading will save farmers the money they keep in the form of reserves in the event of adverse conditions. In addition, daily checking of future prices will enable them to plan production more clearly, and open price information will ensure equal competition.

It should be noted that futures trading mechanisms have not yet worked in the domestic agrarian market. This requires a lot of organizational and legislative efforts, overcoming many false stereotypes and barriers to the goal. The Agrarian Exchange is now preparing to create a fixedterm market that will introduce futures contracts in the national currency, an electronic trading platform and other innovations. Futures are expected to appear on the market in a few years. The implementation of these measures will positively affect the development of the agricultural market in particular and the formation of the national economy of Ukraine in general.

\section{REFERENCES}

[1] John C. Hull, Options, futures and other derivative financial instruments. 10th ed. New York, USA: Pearson Education, 2018.

[2] D. R. Sanders and S. H. Irwin "New evidence on the impact of index funds in U.S. grain futures markets", Canadian Journal of Agricultural Economics, Revue canadienne d'agroeconomie, vol.7, pp. 5-8, 2011.

[3] Ruban Yu.V. "Insurance risk in the price of grain with futures contracts", Efektyvna ekonomika, vol. 2, 2015 [Online]. available at: http://www.economy.nayka.com.ua/?op=1\&z=3828 Accessed on: 26 Aug 2019. [in Ukrainian]

[4] Slobodyanik A. and Avramenko A. "Future trade as a method for solving the price problem on ukrainian commodity markets", Agrosvit, vol. 7, pp. 37-44, 2018. [in Ukrainian]

[5] WFE IOMA 2018 derivatives report. [Online]. Available: https://www.world-exchanges.org/news/articles/world-federationexchanges-publishes-annual-ioma-derivatives-report. Accessed on: August 13, 2019.

[6] Report NSSMC 2017. Online]. Available: https://www.nssmc.gov.ua/reports/ Accessed on: August 13, 2019.

[7] Narang M. "Impact of capital structure on firm performance: A study of listed firms on national stock exchange." International Journal of Advanced Educational Research vol.3., pp. 251-254, 2018.

[8] Sharif T., Purohit H. and Pillai R. Analysis of factors affecting share prices: The case of Bahrain stock exchange. International Journal of Economics and Finance, vol. 7(3), pp. 207-216, 2015.

[9] Bernstein A., Hughson E., and Weidenmier M. Counterparty risk and the establishment of the New York Stock Exchange clearinghouse. Journal of Political Economy, vol. 127(2), pp. 689729, 2019.

[10] Baboukardos D. and Rimmel G., Value relevance of integrated reporting disclosures: evidence from the Johannesburg Stock Exchange. Journal of Accounting and Public Policy, vol.35(4), pp.437-452, 2016. 